\title{
Just add water: colonisation, water governance, and the Australian inland
}

\section{Leah M Gibbs}

Department of Geographical and Earth Sciences, East Quadrangle, University of Glasgow, Glasgow G12 8QQ, Scotland; e-mail: Leah.Gibbs@ges.gla.ac.uk

Received 16 July 2008; in revised form 23 February 2009; published online 19 October 2009

\begin{abstract}
Water has played a key role in the development of the Australian inland and the nation. For European colonists, the dry and variable landscape challenged ideas about nature imported from northern temperate regions. I argue first, that colonists brought with them ideas for ordering nature and tools for transforming landscapes that led to inappropriate and destructive water management and the silencing of local voices and knowledge systems. Secondly, colonial patterns of ordering and transforming landscapes are ongoing, but new ways of governing water, which challenge colonialism, are emerging. In the first section of the paper I discuss colonial relationships with water; in particular the methods of irrigation, river diversion, and bore drilling. In the second section I consider contemporary manifestations of colonial relationships between humans and water, focusing on the bureaucratic separation of land and water, the problematic definition of a river, and the ongoing desire to drought-proof the inland. In the third section I examine emerging ways of governing Australian water, which emphasise knowledge and interconnection, and in so doing challenge ongoing colonial relationships. I describe these two ways of governing water as existing in tension; a tension between engineering-based and knowledge-based approaches to water governance.
\end{abstract}

\section{Introduction}

Observing pelicans flying inland, and tracing river paths towards the continent's centre, early colonists surmised that central Australia held a great freshwater source (Beale, 1979). At the heart of this fabled 'inland sea' is Lake Eyre, a large salt lake (measuring $9300 \mathrm{~km}^{2}$ ) in eastern central Australia. Lake Eyre is often dry but receives water episodically from the Georgina and Diamantina Rivers and Cooper Creek in the north and east, and from a system of smaller rivers in the west. Local rainfall contributes little, with an average annual figure of just $100 \mathrm{~mm}$ (Knighton and Nanson, 1994). Occasionally, Lake Eyre is transformed into a vast freshwater lake but, with evaporation rates greater than $3000 \mathrm{~mm}$ per year (Allan, 1990), the fresh water never lasts long. Although it was a permanent home to Aboriginal people-as it is today - this dry and variable landscape confounded the colonists. It challenged their ideas about nature and about the livelihoods that would be possible in Australia. The inland came to represent both the 'dead heart' of the continent and an opportunity to develop the emerging nation.

In this paper I argue first, that Australia's colonists brought with them ideas for ordering nature and tools for transforming landscapes that led to inappropriate and destructive water governance, and to the silencing and exclusion of Indigenous voices and local knowledge systems. Secondly, colonial patterns of ordering and transforming nature are ongoing, but new ways of governing water that challenge colonialism are beginning to emerge. I describe these two ways of governing water as existing in tension: a tension between engineering-based and knowledge-based approaches to water governance.

The role of colonisation in ordering nature is well documented (eg Braun, 2002; Head, 2000; Howitt, 2001; Rose, 1999; 2004a; Willems-Braun, 1997). Anthropologist Deborah Rose argues: 
"we settlers, or settler-descendants, are the inheritors of the spoils of a dual war: one war was fought against the natives, and one against nature" (2003, page 53). Among its direct physical impacts, colonisation has been responsible for the introduction of new species, disease outbreaks in humans, plants, and animals, forest felling, the systematic slaughter of native animals, and the exploitation of resources for profit (Huggan and Tiffin, 2007). Colonisation also involves the importation of ideas about nature; perhaps most significant among them, the separation of nature and culture which is central to European modernity (Gregory, 2001; Suchet, 2002). Through colonisation a particular nature is normalised-one that is European and temperate, "moderate, constant ... without extremes of excesses" (Gregory, 2001, page 89). European notions of managing nature ontologically privilege European ideas about nature and non-Indigenous ways of being-in-place (Howitt and Suchet-Pearson, 2006; Johnson and Murton, 2007).

Water plays a key role as a tool of colonisation and development (Gedicks, 1993; Powell, 1989; 2000; Reisner, 1986; World Commission on Dams, 2001; Worster, 1992). This role is connected both to the physical interventions that transform landscapes for settlement and development (eg power generation, navigation, flood hazard reduction, water storage), and to the ideas about ordering nature inherent in the colonial project. Engineering strategies physically control and dominate water for development (Cosgrove and Petts, 1990; Gandy, 2003; Kaika, 2005; 2006; Powell, 1989; Swyngedouw, 1999), and contemporary neoliberal water governance involves conceptual and bureaucratic tools for ordering nature-including the privatisation and commodification of water (Bakker, 2003; 2007; Robertson, 2000).

The specific experience of colonial and neocolonial relationships with Australia's highly variable nature is the topic of extensive research (eg Griffiths and Robin, 1997; Head, 2000; Head and Muir, 2006; Howitt, 2001; Rose 1999; Suchet, 2002). Water research is particularly well developed, due both to the centrality of water in the development of the nation and to the growing contemporary water crisis (eg Allon and Sofoulis, 2006; Gibbs, 2006; Goodall, 2002; Head and Muir, 2007; Jackson, 2006; Jackson et al, 2005; Morgan et al, 2006; Powell, 2000; Rose, 2004b; Toussaint et al, 2005; Weir, 2007). This work has resonance for understanding relationships with nature in other colonised places, and also for casting the postcolonial gaze back to imperial centres (Chakrabarty, 2000; Robinson, 2003) in order to understand the effects of colonial policy and examine what have become hegemonic strategies for environmental governance.

In recent research, new ways of knowing nature that get away from neocolonialism and neoliberalism by emphasising hybridity and the coconstitution of nature and culture have been developed (eg Castree and Braun, 2001; Whatmore, 2002). Work drawing on the Australian experience in this tradition investigates hybrid natures and the cultures of nature (eg Head and Muir, 2006) and the theme of interconnection (eg Rose, 1999; Toussaint et al, 2005). Specifically, much recent research is concerned with imagining new ways of knowing and governing Australian water, focusing on, among other themes: water and everyday practice (Allon and Sofoulis, 2006; Head and Muir, 2007); paradigmatic shifts in river management away from engineering principles and towards ecosystem-centred, adaptive, and participatory approaches (Hillman and Brierley, 2005); the emergence of environmental justice as a principle of governance (Hillman, 2006); and the development of structures and processes for Aboriginal participation in water governance (Jackson, 2006; Morgan et al, 2006; Weir, 2007).

In this research I employed a range of methods. Analysis of historical and contemporary literature and water-management and land-management documents revealed colonial relationships with Australian nature and the inland, and contemporary manifestations of these relationships. Work consulted included federal and state water policy, 
accounts of the inland by explorers, scientists, and settlers, and studies of the development of water-management ideas in Australia. Empirical research in the Lake Eyre Basin, eastern central Australia (figure 1) was conducted during three field sessions in 2002 and 2003. In particular, I used participant observation at three water-management and catchment-management fora, and conducted in-depth interviews with thirty-two people living and working in the basin. Interviewees included pastoralists, Aboriginal residents and representatives of Aboriginal organisations, ecological scientists, town residents, mining and petroleum company representatives, tourism operators, and natural resource policy makers and decision makers. Initial interviewees were suggested by two contacts involved in water governance in the basin; further interviewees were identified using a snowballing technique. References to interviews appear in the form surname and date of interview.

The first section of this paper examines colonial relationship with water and the inland, and the role of water in developing the inland and the nation; in particular, the methods of irrigation, river diversion, and bore drilling. The second section considers contemporary manifestations of colonial relationships between humans and water, focusing on the bureaucratic separation of land and water, the problematic definition of a river, and the ongoing desire to drought-proof the inland. The third section explores emerging water governance strategies that challenge colonial relationships with water by emphasising interconnection, knowledge of particular place, and diverse knowledge systems.

\section{Colonial relationships with water: ordering nature and transforming landscapes}

The colonial imperative to develop the inland and the nation has been key to Australian relationships with water. Early settler expectations of land, water, and livelihood were based on the regularity and predictability of European water regimes.

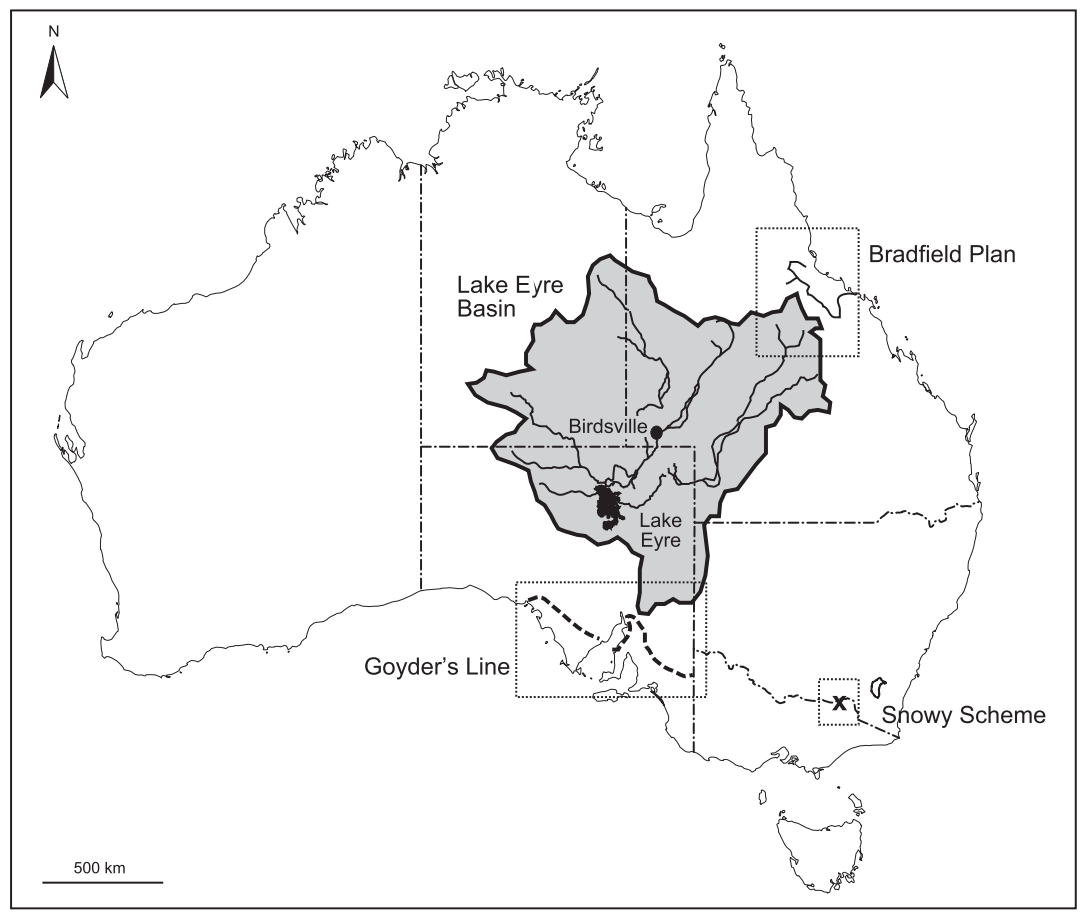

Figure 1. Australia, showing location of sites mentioned. 
However, what settlers confronted in the inland was a dry and variable climate-what Cecil Madigan (1946) later evocatively described as The Dead Heart. At the time of colonisation, Aboriginal people lived permanently in the heart of the continent. They relied on a combination of temporary surface water and groundwater. Ephemeral water sources included: swamps and claypans; depressions in clay soils ('crab-holes' or gilgai) and in limestone or granite rocks, enlarged by people over time to increase their capacity (ngamma); and drains and small dams across claypans, which channel or hold back water. Water can also be found in the roots of Hakea leucoptera, in the bodies of aestivating frogs (Cyclorana platycephala), which burrow underground during the hot summer months, and by watching other animals, such as kangaroos, digging for water (Bayly, 1999; Hercus, 1985; interview, McEntee, April 2003). When temporary water disappeared, desert people returned to the mikiri, or native wells-desert wells cared for by Aboriginal people (Hercus and Clarke, 1986).

This complex system of ephemeral and permanent water was supported by understanding of interconnections between land and water, and by rights to and responsibilities for water (Jackson et al, 2005; Langton, 2002; Rose, 2004b; Toussaint et al, 2005). Rose explains that

"on-going subsistence depended on control of resources, and this is a matter of life and death. For example, one cannot plan to rely on a certain place that is a source of fresh water, only to arrive and find that somebody else has used it all up. ... On the other hand, flexibility is also a key factor. Indigenous people's main adaptation to uncertainty was to develop social ties that enabled people to move to resources as they became available" (2004b, pages $36-37$ ).

Explorers and settlers commonly relied on Aboriginal people and their knowledge of the land, and in particular freshwater sources, for survival (Langley, 1969; Stokes, 1986). Yet the diaries of some tell of their exploitation of the water sources that Aboriginal people carefully maintained. Ernest Giles, during his 1875 expedition in South Australia, wrote:

"we came to a place where there was a considerable fall into a hollow, where there existed some bare clay ... the surface was perfectly dry, though in a small drain or channel, down which in times of rain, water would descend to it, by the blessing of Providence we stumbled on a supply of yellow water. ...when I led the camels to the place, down they fell on their knees in the mud and water, and drank and drank, and I again joined them and also drank, and drank, and drank. Ah! dear reader, if you have never suffered thirst you can form no conception what agony it is. But, talk about drinking, I couldn't have believed that even thirsty camels could have swallowed such enormous quantities of fluid" (Giles, 1979, pages 28-29).

Settler Australians have long sought to transform Australia's landscapes (Powell, 2000). Water, in particular, did not fulfil the expectations of colonisers (Arthur, 2003; Robin, 2007). The continent's water regimes posed significant challenges to European understandings of nature and systems of agriculture. Adding water to this strange, dry landscape - greening the drought-ridden continent-quickly came to represent a solution to the perceived problem of the 'dead heart'. The late 19th century brought water-management tools of irrigation, river diversion, and bore drilling, making it possible to bring water to dry landscapes from regions of relatively high rainfall or river flow, and from underground sources. Transplanting water from one place to another separates water, physically and conceptually, from its constituent parts (land and plant and animal life) and from its context (place, lives, meanings, and institutions). Such separation has become a central concept in contemporary natural resource management (a theme I discuss later). Engineering enabled water to become the primary tool of development in Australia, as it has been elsewhere (Cosgrove and Petts, 1990; 
Gandy, 2008; Kaika, 2006; Reisner, 1986; Swyngedouw, 1999; Worster, 1992). Engineering strategies explicitly aimed to transform nature, and to subdue and control water, and in so doing silenced local knowledge systems, ontologies, and voices. In the remainder of this section I explore the dominant methods of transforming nature and the ideas that informed them.

\section{“Just Add Water": irrigation}

"With irrigation ... there is no dead season in the year."

Elwood Mead (1914, page 258)

Irrigation quickly became the solution to the problem of Australia's lack of water, and thus the primary tool for making land productive and developing the emerging nation. The connection between irrigation and development was strong, as was the belief that Australia's water scarcity had hindered the nation's development (Davidson, 1969). Under the Chairmanship of Alfred Deakin (later Commonwealth Prime Minister), the state of Victoria's Royal Commission on Water Supply 1884 deemed irrigation to be a "sound investment" and necessary to "progress" if Victoria was to "utilise her abundant natural advantages, bring her productiveness to the highest point, and secure to the agricultural population of her arid districts a permanent prosperity" (quoted in Powell, 1976, page 131). Deakin drew heavily on experiences in the United States to justify major irrigation development, and called upon the expertise of Elwood Mead, Chairman of Victoria's State Rivers and Water Supply Commission (1907-14). For Mead, the new irrigation-based settlements provided a stable base from which further expansion into marginal country was possible.

Mead enthusiastically promoted irrigation - at its core a process of dissembedding water from its context and constituent and dependent parts. Concurrently, he promoted the connection between land and water:

"No adequate system of irrigation laws, or any enduring prosperity for the people who till the soil, can be built on separate ownership and divided control of land and water. The fundamental condition of success is that these two joint agents of production should be disposed of together, and that with every title to irrigable land should go an interest in the stream which gives it value" (Mead, 1903, page 23).

Mead's claim that "With irrigation ... there is no dead season in the year" (1914, page 258), reveals much about attitudes to and expectations of irrigation and Australia. Not only would irrigation overcome the vagaries of Australia's climate, it would enable year-round production - thereby overcoming the seasonal variation in productivity experienced in all agricultural landscapes.

Despite its political popularity, the efficacy of irrigation was strongly questioned by a number of scientists and government employees who argued that environmental factors would limit development. In particular, the work of George Goyder (1826-98), Griffith Taylor (1880 - 1963), Francis Ratcliffe (1904 - 70), and Bruce Davidson (1924-94) roused public controversy (Handmer et al, 1991). Goyder was Surveyor-General of South Australia between 1861 and 1894. After just over fourteen years in the colony, Goyder had grasped the reality and impact of variable rainfall, and mapped a border within South Australia beyond which rainfall was too unpredictable to sustain European-style agriculture (Sheldrick, 2005). Described in 1865, 'Goyder's Line of Rainfall' (figure 2) was intended as an administrative tool to guide government provision of drought relief during the Great Drought of the mid-1860s (Meinig, 1962; Powell, 1976; Sheldrick, 2005). The line described the extent of reliable rainfall; however, the subtlety was quickly lost. It became commonly understood as a line of average annual rainfall; an estimation of aridity rather than variability (Sheldrick, 2005). Goyder's Line was popularly understood to represent the extent beyond which agricultural production 


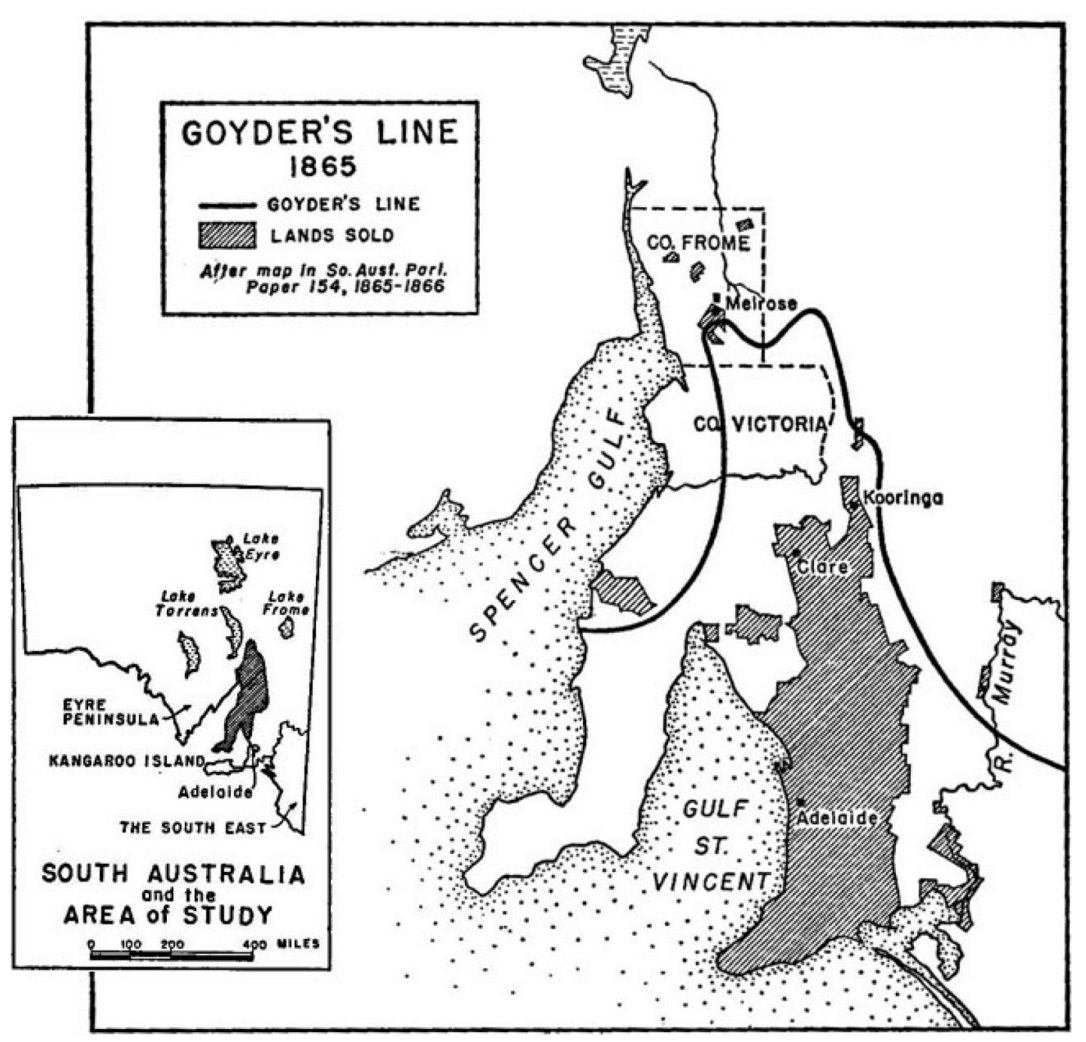

Figure 2. Goyder's Line, South Australia (adapted from Meinig, 1962).

was not viable, and was officially endorsed as the frontier for agriculture. After the Great Drought, the 1870s was marked by high rainfall north of Goyder's Line. Increasing pressure for agricultural land, coupled with successive years of high rainfall, led to farmers moving north in increasing numbers. Goyder's Line came to be widely ridiculed, and was abandoned as a limit to intensive agricultural settlement.

In the 1920s geographer Griffith Taylor challenged the popular belief that Australia could sustain 500 million people. Describing limits imposed by the environment, he estimated a population of 20 million by the year 2000 (Handmer et al, 1991) (a figure that was reached in 2004). Taylor was derided for his unpatriotic assessment that Australia was a continent beset by drought (Sheldrick, 2005). In the 1930s British biologist Francis Ratcliffe was commissioned to conduct a survey of the problem of erosion and soil drift in South Australia (Ratcliffe, 1938). He found that the land was not suited to the settlers' economy or way of life (Dunlap, 1997), and criticised the refusal of Australians to recognise 'drought' as a normal part of Australia's environment and climatic regime. In his final report Ratcliffe concluded:

"pastoral settlement in the arid belt (or anywhere else for that matter) was merely self-destructive if the system of stocking and management practiced led to the progressive depletion of certain of the most important components of the pastures. If settlement was to be on a permanent and stable basis, stocking must be in equilibrium with the vegetation; that is to say, it must permit complete recovery of those plants that are periodically over-grazed. Deterioration, erosion, and drift will increase with every recurring drought unless the stocking policy is adjusted to suit the conditions imposed by the climate and the vegetation" (1938, pages 324-325). 
In 1938 he wrote that in the year that had passed since completing the report his mind had been "haunted by doubt" (page 325):

"Was there any system of stocking and management, workable and economic in practice, that would preserve the vegetation of the semi-arid country, and thus ensure the survival of human settlement in these areas? This was the question that kept hammering in my head. Worry and puzzle as I might, I could see only one answer; and it was not the answer I had hoped to find" (page 326).

Ratcliffe's analysis was based on economic, social, and ecological factors, and the relationships, processes, and limits imposed by the environment. His recommendation that pastoral lands be consciously destocked in order to preserve the country was politically and socially unpopular (Dunlap, 1997; Robin, 1997). In 1969 Bruce Davidson presented further controversial critiques of irrigation, focussing on physical and economic limits to development:

"Australians will only cease to believe that irrigation is a profitable means of using the nation's resources when the part it has played in the nation's economic development is accurately measured, and the future profits which can be expected from new irrigation schemes are contrasted with the greater returns which might be expected from other forms of development. The faith in irrigation as the cure for drought will only be erased when the part played by irrigation areas during periods of drought is accurately described" (page 5).

Like Goyder, Taylor, and Ratcliffe, Davidson emphasised Australia's climatic variability and the associated fluctuations in agricultural production. All four attempted to normalise drought as a part of Australia's climatic regime. However, because they questioned popular attitudes towards Australia's environments, and criticised the unquestioned faith in the power of irrigation, their work was branded 'unpatriotic' and was widely derided, highlighting the unwillingness of settler Australians to accept the continent's variable climate, and pointing to the connection between nature and nationhood (see also Ginn, 2008; Jazeel, 2005; Robin, 2007).

\section{"Turning the rivers inland": water diversion}

As irrigated agriculture grew and rivers were exhausted, additional water sources were sought. So began the focus on 'turning the rivers inland': diverting flow from coastal rivers to river channels draining towards the dry interior. Many Australian coastal rivers lie in areas that receive higher rainfall than adjacent inland regions-notably those along the eastern seaboard, separated from the inland by the Great Dividing Range. In these relatively high rainfall areas extensive irrigation is often not required, or is made unfeasible by topography. Water in coastal rivers was considered to be 'wasted' because it did not contribute to irrigation and therefore to development of the nation.

River diversion had been discussed in the 1884 Royal Commission on the Conservation of Water, and again in 1903 by the Interstate Royal Commission on the River Murray (Davidson, 1969). The intensity of irrigation development in the southeastern Murray River and the drought in the western plains of New South Wales during the 1880s turned the gaze of water managers to possibilities for river diversion in the southeast. The Snowy Mountains Scheme was the result of over sixty years of proposals and speculation (McHugh, 1989), and was the first and only significant realisation of the plan to 'turn the rivers inland' (see figure 1). The project was begun in 1949, and involved damming the headwaters of the Snowy River and diverting its flow through a series of tunnels into the Murray and Murrumbidgee Rivers. It is a flexible engineering system in which water can be pumped or released between several lakes and reservoirs, depending on need. At times, the Snowy River will flow via its original path, at others it will be transported across subcatchments, or pumped under 
the Main Range of the Snowy Mountains (Seddon, 1994). The scheme is a joint project of power generation and water 'conservation' for irrigation.

Perhaps the most ambitious river-diversion project proposed in Australia was the Bradfield Plan (figure 3). Initially conceived by one of Australia's most celebrated engineers, John Job Crew Bradfield, in the 1930s, and promoted by the immensely popular writer Ion Idriess (Idriess, 1941; Timbury, 1944), the Bradfield Plan aimed to divert flow from northern Queensland coastal rivers. Bradfield suggested that the headwaters of the Tully, Herbert, and Burdekin Rivers could be dammed, their reservoirs linked by a series of tunnels, and their cumulative flow diverted through the Great Dividing Range. This water would enter the upper reaches of the Thomson River, and flow inland towards Lake Eyre. The plan aimed to transform arid central Australia: to 'water the inland'; to 'make the desert bloom' (Davidson, 1969; Powell, 2000).

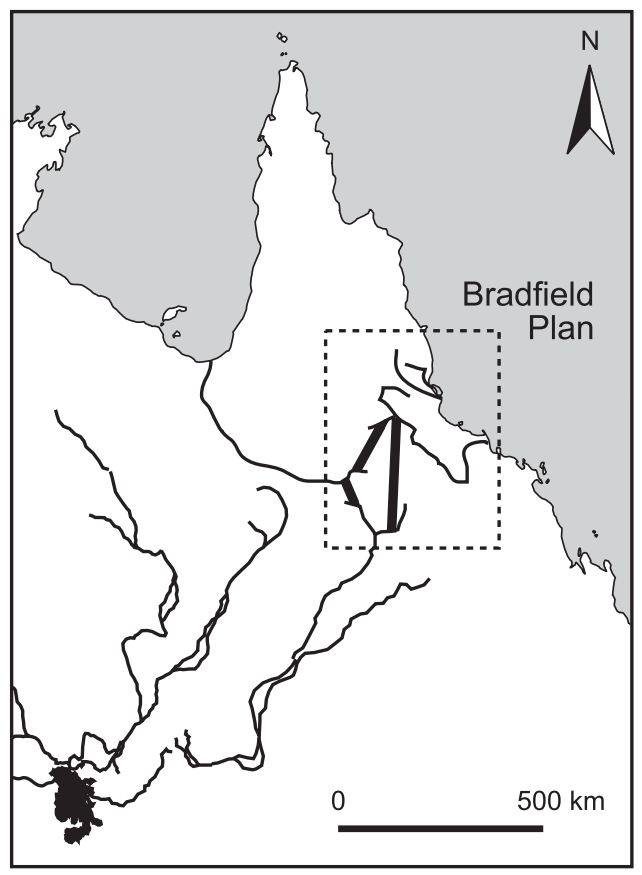

Figure 3. The Bradfield Plan, showing major river-diversion tunnels.

According to Bradfield's proposal, dams could be built across the Georgina and Diamantina Rivers and Cooper Creek in southwestern Queensland and used to irrigate millions of acres, converting marginal pastoral land into productive agricultural land. Bradfield made a more radical argument that these new expanses of water would in turn lead to an increase in rainfall over a much larger surrounding area (a claim that remains unsubstantiated). The myth of making the desert bloom through river diversion is persistent, and has been the driving force for numerous reworkings of Bradfield's Plan into the present (as I discuss below).

\section{Drilling for water: artesian bores and boredrains}

Like irrigation and river diversion, artesian bores transformed the landscape and human relationships with the inland. The practice of drawing groundwater to the surface was central to the colonial settlement of arid and semiarid Australia. Settlers found springs and shallow groundwater sources - often with the help of Aboriginal people - very early in the period of expansion into inland Australia, but the discovery 
of the deep and extensive Great Artesian Basin in the late 1870s precipitated dramatic change by providing the reliable water required to develop the inland for pastoralism. Permanent settlement based on cattle grazing could be made viable with increased and reliable water supply. Since about 1883 the bores of the Great Artesian Basin have provided a constant water supply to pastoral properties and townships in the regions overlying the aquifer, including much of the Lake Eyre Basin (Yelland, 2002).

Tapping the Great Artesian Basin enabled establishment of relatively safe stock routes from inland floodplain pastures to distant railheads and markets. The most important of the Lake Eyre Basin stock routes, the Birdsville Track, formed a path from the 'Channel Country' of Cooper Creek and the Georgina - Diamantina Rivers to the railhead at Marree. From 1890 ten artesian bores were drilled along the Birdsville Track, spaced at roughly two-day cattle-walking distances; all ten bores were in operation by 1916 (Yelland, 2002). Away from the stock routes, artesian bores allowed stocking rates and practices that were not possible at pastoral properties that relied on river water and rainwater. With artesian bores pastoralists were able to take water to parts of properties that did not otherwise receive water, and to spread their stock out away from rivers and waterholes to the unwatered gibber plains (the stony pavement surface that characterises much of the inland away from rivers and dunes) where perennial grasses grow. In towns a bore altered people's daily lives by ending the need to cart water from the river each day, thereby changing relationships with the river (interview, Rowlands, April 2003).

When bores were first drilled in the Lake Eyre Basin, little was known about their source, and groundwater supplies were essentially considered to be endless (Cox and Barron, 1998). In many parts of the Great Artesian Basin water was held below ground at sufficient pressure to enable it to reach the surface through a drilled bore without being pumped. Many artesian bores were constructed as free-flowing; once water reached the surface it flowed out across the landscape, running to a natural depression, following a creek-line, or filling a drainage ditch dug for the purpose (figure 4).

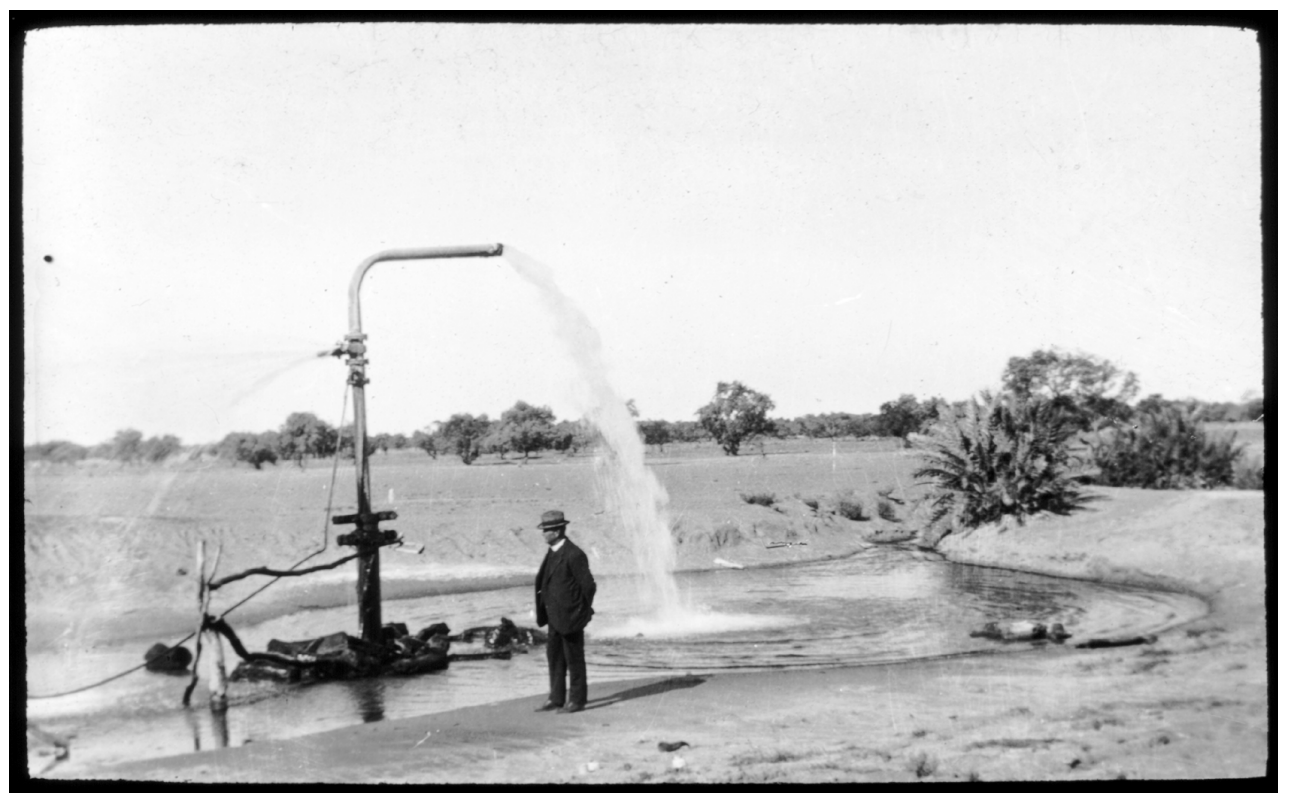

Figure 4. Free-flowing bore at Bedourie, southwest Queensland, 1927 (source: National Library of Australia, nla.pic-an24669531). 
The result is a boredrain. Boredrains provide a low-maintenance method of dispersing water for cattle and allowing hot groundwater (sometimes close to boiling point) to cool sufficiently for stock to drink. Bores transformed the landscape by creating new water places, which altered the local ecology and essentially made the inland a more 'watered' landscape.

Over time, the water extracted from the Great Artesian Basin by bores has led to draw-down of the aquifer, which has reduced pressure in the basin and in turn led to increasing numbers of bores and springs running dry. Springs form rare permanent water sources in the desert, supporting plant and animal life. Many, such as the mound springs complex south of Lake Eyre and Dalhousie Springs to the west, are highly significant to local Aboriginal people (Ah Chee, 2002; interview, Dodd, May 2003), and also have historical value in the inland's colonial history. Rates of recharge to the Great Artesian Basin are difficult to determine, but it is widely agreed that extraction is far greater than recharge (Cox and Barron, 1998). Concern over conservation of artesian waters, combined with technological development, has led in recent years to a basin-wide project to cap free-flowing bores, allowing flow to be controlled. However, several thousand free-flowing bores exist, and at many water emerges at the surface under very high pressure and at high temperature, making this a long and difficult process. Like irrigation and river diversion, bores provided an engineering solution to the perceived problem of the variable rainfall and river flow that characterise inland Australia. All three strategies transformed landscapes and people's relationships with water and the inland, and their effects continue to be felt.

\section{Contemporary manifestations of colonialism}

Colonial ideas about ordering nature continue in contemporary water governance. Nature is transformed physically, conceptually, and bureaucratically through neocolonial and neoliberal governance strategies - strategies which are based on European knowledge of European landscapes, which ignore local specificity, and which aim to overcome the variability of local water regimes. Contemporary strategies continue to silence diverse knowledge and voices and perpetuate destructive water-management practice. In this section I consider three examples of the contemporary manifestation of colonialism: the separation of land and water by the Council of Australian Governments; the ill-fitting definition of a river used in policy and legislation; and renewed calls to turn rivers inland.

\section{Separation of land and water: CoAG water reforms}

In the 1880s Deakin had adhered to advice from the US "to protect the fundamental indivisibility of land and water" (Powell, 1989, page 107). Water and land were tied with the purpose of preventing monopolisation of water rights and development of watermarket speculators (Connell et al, 2005; Powell, 1989). One hundred years later, US water policy was once again influential in Australia: this time American economist Alan Randall (1981) presented a water-reform proposal for transferable water entitlements that demanded separation of land and water. Following advice from Randall and others, in 1994 the Council of Australian Governments (CoAG) committed to a process of water reforms that separated land and water in order to facilitate water trading. This process firmly established water as a commodity separate from land, consistent with the neoliberal process of commodification of water in other parts of the world (Bakker, 2003; Robertson, 2000). The National Water Initiative 2004 (NWI) revisited the 1994 water reforms. 
In a report by the Commonwealth Scientific and Industrial Research Organisation (CSIRO) Mike Young and Jim McColl describe the perceived benefits of separating water and land:

"Separation of the interest into its component parts facilitates development of more economically efficient management and accounting systems. It facilitates adjustment of part of the system without having to review the whole system. This reduces transaction costs. Moreover, risk management is more efficient when each type of risk is managed separately" (2002, page 25).

This approach prioritises economic efficiency over complex interconnections between physical, ecological, social, and cultural systems. The water reforms and NWI enshrine water trading - and therefore separation of land and water - as a legitimate and desirable form of human interaction with water and the environment.

The colonial methods of irrigation, river diversion, and bore drilling separated water and land physically: water was extracted from relatively well-watered places, above or below ground, and transported to drier places. Contemporary water governance sees the continued use of these tools combined with new forms of bureaucratic separation. Both sets of approaches seek to order nature and transform landscapes in order to overcome the variability of Australia's water regimes. Through the separation of land and water, rivers are transformed into conduits for water as a commodity. Separation has particularly significant implications in areas with highly variable rainfall and river flow and extensive floodplains. It overrides local variability and vital interconnections, for example: the role of water in forming, creating, and transforming landscapes; the coconstituency of land and water, and living and nonliving things reliant upon them; livelihoods dependent on episodic floodplain inundation; and values associated with water (see Gibbs, 2006).

\section{Definition of a river: overland flow and the Queensland Water Resources Act}

Effective governance of Australia's dryland rivers is hampered by the definition of a river used in policy and legislation guiding water and catchment management. The Australian Macquarie Dictionary (1997) defines a river as "a considerable natural stream of water flowing in a definite course or channel or series of diverging and converging channels." The Queensland Water Resources Amendment Act 1998 (amending the Queensland Water Resources Act 1989) is, among other legislation, based on such a definition. Yet many rivers in inland Australia are characterised by ephemeral flow that occurs largely outside the confines of definite channels [see Taylor and Stokes (2005) for a detailed discussion of the ongoing problem of the definition of a river in New South Wales]. Just as colonial relationships with water and the inland were based on knowledge of European landscapes, the definition of a river used in Australian legislation ignores the specificity of Australian water and local knowledge of water regimes.

The definition of a river becomes particularly problematic in the Channel Country - the region of the Lake Eyre Basin characterised by multichannelled ephemeral rivers and vast floodplains, at times and in places up to $60 \mathrm{~km}$ wide (Knighton and Nanson, 1994). These floodplains support a diverse ecology dependent on episodic flooding. They are also used by the cattle industry, which exploits the pasture left behind when floodwaters recede. Pastoralists and ecologists who live and work in the Channel Country know these rivers well; their knowledge makes them acutely aware of the implications of an ill-fitting definition. Bruce Scott, owner and manager of cattle property Moothandella Station in southwest Queensland, explained:

"The Channel Country is so different to other rivers, in the way that it flows, the way that the regime happens when it runs. And this is probably something that 
you'd never get through to government, but there needs to be a separate legislation for dealing with how it's described. In English law [a river is] described as a bed and banks. Well, it's nothing like that. It may have a bed and bank when it stops running, as in waterholes. People talk about flooding. Well it doesn't flood, it just runs. And inundates its path" (interview, Scott, May 2003).

Under existing legislation, floodplains and some distributary channels are not defined as watercourses, so few restrictions apply (Kingsford, 2000). When these rivers are in flood, a large proportion of the water travels across floodplains. Bob Morrish, owner and manager of Springfield Station, explained that in recent years the Queensland government has begun addressing the issue of overland flow:

"When Rod Weldford was Minister [for Environment, Heritage and Natural Resources] he instituted a process for covering a huge gap in water-resource management, in relation to the management of what the Queensland government anyway call 'overland flows'. In other words, water on floodplains; basically water on floodplains that's not in defined channels. Because there is this problem: the Water Resources Act still talks about ... this concept of a 'water course', and that's something that's meant to look like a conventional European river. And quite clearly the major transport of water in the Channel Country rivers and the arid rivers is not through the actual main channels, but during floods it's over the floodplains. And as of about 1999, 2000 the Water Resources Act still had no control over developments on floodplains" (interview, Morrish, May 2003).

The implications are not lost on local people:

"to my knowledge they still haven't cleaned up the Water Resources Act to the extent that we could, for instance, stop a developer buying this place here and building a low bank .... Any earth structure under five metres high is not what's called 'licensable' under either the Water Resources Act or the Planning Act .... So a person could build a 5 metre high bank from one side of this floodplain to the other, as long as they didn't build it in the actual channel. And they could block up all the water on that floodplain. I could do it; I think I would still be legally entitled to do that. Now that is a very big problem" (interview, Morrish, May 2003).

The possibility of such development became a real threat in the 1990s when a large cotton-irrigation development, involving 'off-stream' storage, was proposed for Cooper Creek at the property Currareva. The proposal was fought successfully by an unlikely alliance of pastoralists, ecologists, and conservationists (see Walker et al, 1997).

Importation of meanings from elsewhere is characteristic of colonial ways of ordering nature. The definition of a river used in Australian legislation is indicative of the contemporary manifestation of colonial relationships with Australian nature, which ignores the specificity and variability of local landscapes and water regimes in favour of European knowledge of European places. Further, it is likely to have tangible effects for water governance by biasing treatment of dryland rivers for conservation, management, and research (Kingsford, 2000).

\section{Drought-proofing and the persistent myth of the inland sea: Farmhand Foundation}

Since Bradfield first proposed his plan for major river diversion in the 1930s, the idea has enjoyed multiple revivals - most recently in October 2002. During the drought or dry period experienced in many parts of Australia during the first years of this century, the desire to 'turn the rivers inland' was once again voiced publicly. This time the promoters were a group of prominent Australian business and media barons. (It is perhaps not coincidental that these men have significant interest in cattle-grazing businesses in drought-affected areas). The Farmhand Foundation called for Australians to "Lend a Hand" in providing "immediate relief to families suffering the affects 
of drought". In addition to their fundraising activities, the Farmhand Foundation aimed to "promote long term strategies to help 'drought proof' Australian agriculture" (Farmhand Foundation, 2002). River diversion - and in particular Bradfield's visionwas actively promoted in the early stages of the organisation. The Farmhand Foundation website promoting the plan has since been updated, following the release of a report commissioned by the Foundation, which recognises the ecological and economic barriers to major river diversion (Osborne and Dunn, 2004).

The language of 'drought proofing' and 'drought mitigation', and the ongoing debates around these themes, once again illustrates the importation of ideas about nature from northern temperate regions (Arthur, 2003). To Bradfield, and proponents of his plan, 'drought mitigation' means ensuring a constant and reliable supply of water. An alternate way of imagining 'drought mitigation' might involve recognising that drought is a normal part of Australia's climatic regime, and that 'drought' is not simply a physical phenomenon but a social and cultural perception of the impacts of climatic variability on agricultural practices. In this way of thinking, 'drought mitigation' might be differently conceived as preparations, or alterations to practice, designed to limit potential negative impacts of climatic variability on economic activity, production, and livelihood. Rather than ensuring regular water supply irrespective of season, rainfall, and river flow, 'drought mitigation' might come to mean interactions with place that are not dependent on regular, secure water supply, but which reflect specific local water regimes.

The vision of a well-watered inland promoted by Bradfield, and revived by the Farmhand Foundation, recalls days of European explorers searching for the mythical inland freshwater source. The 'inland sea', it appears, has not yet left the national imagination. Environmental and climatic variability are still not widely accepted in Australia. The desire to transform Australian landscapes persists. The Snowy, Bradfield, and other grand plans, as well as the more mundane frequency of farm dams and weirs dotting Australia's waterways, provide physical marks on the landscape. The persistent language of 'drought-proofing' and 'drought mitigation' attests to the attitude of nonacceptance of Australia's environments and variable water regimes, and the ongoing influence of colonial ways of ordering nature. Francis Ratcliffe's 1938 warning of the implications of refusing to accept drought as part of Australia's variable climate and environments retains its urgency.

\section{Towards new ways of governing Australian water: knowledge and interconnection}

In recent decades, water governance that perpetuates colonial relationships has been countered by approaches that challenge these relations. Emerging strategies emphasise knowledge of particular places, diverse knowledge systems, and interconnections between water and ecological and social systems. These new approaches have not replaced neocolonial governance: rather, the two exist in tension-a tension I characterise as existing between engineering-based and knowledge-based governance. In this section I discuss the emergence of new water governance strategies in the Lake Eyre Basin that challenge colonial relationships with nature.

Two conflicts over water during the 1990s stimulated new water governance structures and processes. Proposals for World Heritage listing of parts of the basin (Jenkin, 2001; Reid, 1994) and a major cotton-irrigation development (Walker et al, 1997) prompted conflicts over both use and social constructions of water. Lake Eyre Basin water and water places were variously constructed as pristine wilderness, home and livelihood, untapped economic resource, and key factor supporting the ecosystems, industries, and livelihoods of the basin. These conflicts sparked new and unexpected alliances between pastoralists, conservationists, and ecologists, and stimulated a 
community-driven catchment-management process that led in 1998 to the formation of the Lake Eyre Basin Coordinating Group (LEBCG).

State and federal governments responded to calls from people living and working in the basin for cross-border integrated catchment management by establishing the Lake Eyre Basin Intergovernmental Agreement (Australian Government, 2000). The agreement would see, for the first time, management of water and related resources across state and territory borders. The LEBCG and the agreement were the first efforts to conceptualise the Lake Eyre Basin as an entity for the purposes of environmental governance, and to bring together the interests of industries, communities, and ecosystems. In so doing, they marked a significant step towards acknowledging interconnections between water and social and ecological systems and diverse knowledge of the Lake Eyre Basin.

More recent catchment-related projects continue the process of prioritising interconnection and bringing diverse knowledge systems into conversation. These include Aridflo-environmental flows for Australian arid zone rivers (Costelloe et al, 2003) and WISE - Water Information Systems for the Environment (Kingsford and Davis, 2002). The primary aim of these projects is to improve ecological knowledge of poorly understood ecosystems, but both explicitly seek to integrate scientific and local knowledge to some degree. Scientists working on Aridflo and WISE recognise that the intimate local knowledge and long-term observation often held by local peopleincluding Aboriginal people and non-Indigenous settler pastoralists - cannot be replicated by even the most rigorous scientific research. Aridflo scientist Jim Puckridge described some of the contributions of pastoralists to the project:

"[Local knowledge] hasn't the same rigour as scientific observation ... but it's still useful. Often it can direct your attention to some wetlands rather than others as priorities. And sometimes people have made observations, which are the product of much longer periods of experience of the rivers than we have. So for example [pastoralists] have seen tortoises in the Diamantina, and we had never recorded them, and now we've actually found some" (interview, Puckridge, April 2003).

WISE brings together oral histories and ecological and hydrological observations. Qualitative and quantitative data sit side by side, presenting a more complex picture of catchments than could be gained by scientific or local knowledge alone. Similarly, the Desert Knowledge movement, which has emerged in central Australia in recent years, combines scientific, Indigenous, and other local knowledges of desert environments and strategies for living sustainably in inland Australia, and explicitly acknowledges ontological diversity (Desert Knowledge CRC, 2006).

Integrated catchment management in the Lake Eyre Basin is part of a global move from engineering principles towards ecosystem-centred, adaptive, and participatory approaches to river management. Hillman and Brierley (2005) argue that this shift from top-down government-imposed frameworks to community-based participatory approaches is the most fundamental change seen in river management practice. Catchment management is part of the recent shift in thinking and practice from 'government' towards 'governance', marking a recognition that nature is governed through interactions between state and nonstate, and formal and informal institutions (Bulkeley and Mol, 2003; Himley, 2008). It forms part of a broader move towards recognising interconnections between humans and the nonhuman world and prioritising participation in environmental governance.

The postcolonial era has seen an emphasis on diversity in environmental governance, which has been manifest in participatory methods that seek to engage 'other' voices and experiences (Howitt, 2001); in particular those that lie outside the hegemonic Western development imperative and are often silenced by it (Howitt and Suchet-Pearson, 2006). 
In Australia, as in other colonised nations, this notably includes efforts to involve Indigenous peoples in environmental governance (eg Jackson et al, 2005; Morgan et al, 2006). The new governance strategies described above-the LEBCG and the Agreement - formally acknowledge Aboriginal interests and the importance of Aboriginal community participation. For example, the agreement states that "there will be appropriate representation of Aboriginal interests", and recognises the role of Aboriginal communities in determining that representation (Australian Government, 2000). However, according to both Aboriginal and non-Aboriginal people in the basin, Aboriginal involvement remains poor. Jimmy Crombie, a Wangkangurru man from Birdsville, suggests that the failure to consider Aboriginal issues in a meaningful way is at least in part related to people's fear of the legal doctrine of Native Title:

"With Native Title some of them are frightened they might lose a bit of dirt, or their stock might miss out on a bit of feed. ... People are frightened. They should come and talk to Aboriginal people more and learn about the issues" (interview, Crombie, May 2003).

The failure of existing approaches to incorporate Aboriginal interests effectively is not going unnoticed in the Lake Eyre Basin: during field research the subject was frequently discussed in meetings, interviews, and informal fora. In October 2004 Aboriginal community members from across the basin organised the first Lake Eyre Basin Aboriginal Forum, immediately preceding the biannual meeting of the Lake Eyre Basin Ministerial Forum. The objectives of the meeting were to build relationships among Aboriginal people from different parts of the basin, discuss Aboriginal visions for natural resources, and introduce and discuss Aboriginal involvement in the Agreement (LEBAF, 2006). The second Aboriginal Forum was held in August 2006, and the process is ongoing.

\section{Conclusion}

Colonisation has had a dramatic impact on Australia's physical landscapes and relationships with water. European colonists imported ideas for ordering nature and tools for transforming landscapes from northern temperate places. Together, these ideas and tools signalled a dramatic departure from Indigenous ways of knowing water, silenced local voices and knowledge systems, and led to inappropriate and destructive water governance. Colonial water governance was dominated by engineering approachesmost notably irrigation, river diversion, and bore drilling. These approaches continue into the present, and are partnered by neocolonial bureaucratic strategies for imagining and governing water, including separation of water and land, and imposition of measures that ignore the specificity of local water regimes and silence local knowledge systems.

Historically, the inland sea was to provide the solution to the 'problem' of the Australian landscape. Many Australians, and arguably Australia as a nation, have not yet come to terms with the continent's variable water regimes and poor soils (Arthur, 2003; Head, 2000; Powell, 2000; Rose, 2003). Many still hold on to the idea of the inland sea as a solution for overcoming the incommensurability of water variability and land-use practices chosen by a settler population. The colonial imperative to order and transform nature retains its power through the practicalities of contending with this incommensurability, and the ongoing hopes for developing the nation. The colonial relationship is further reinforced through social and cultural institutions, including land-management regimes and the substantial imagery of Australia developed through art and literature.

However, neocolonial governance exists in tension with new approaches that challenge colonialism. New ways of governing water are emerging in the contemporary 
national context, in that Australia attempts to come to terms with its violent colonial history, evidenced by legal and social changes such as Mabo and Native Title, and the movement towards reconciliation. Internationally, we are witnessing wider recognition of and growing solidarity around Indigenous rights (Howitt, 2001), increasing awareness of the interconnections between humans and the nonhuman world (eg UN Millennium Development Goals; see also Head and Muir, 2006), and growing acceptance of the vital role of broad participation in the governance of nature (Bulkeley and Mol, 2003; Morgan et al, 2006). The tension between neocolonial and new ways of governing water offers a creative possibility as neocolonial governance provides a framework against which to resist.

Water governance that emphasises knowledge and interconnection presents opportunities for overcoming the historical and ongoing silencing of local peoples and knowledge that is familiar in most postcolonial settings. In Australia colonisation continues to have a strong impact on Aboriginal people. Working with Aboriginal people in the Lake Eyre Basin on the development of participatory methods of governance and research (in particular, supporting the recommendations of the Lake Eyre Basin Aboriginal Forum) may facilitate Aboriginal participation. This in turn may lead to healthier relationships between Aboriginal and non-Aboriginal communities, and provide opportunities for listening to and learning from others. Such learning is likely to expand understandings, thereby presenting opportunities for developing new ways of knowing Australian water and the inland, and contributing to the process of addressing the legacy of Australia's colonisation. Experiences of specific settings, as well as those that are common to multiple postcolonial contexts, can provide lessons for other places. Casting the postcolonial gaze back to imperial centres can provide insights for international relations, including international development, and inform local water governance - in particular, highlighting the value of local knowledges.

A postcolonial water governance should aim to provide for the needs of humans and other living things (including complex ecosystems and social systems), and address the historical and continuing marginalisation of local peoples and diverse knowledge systems. In order to achieve this aim we must deepen our commitment to knowledge and interconnection by developing and supporting water governance that emphasises: knowledge of specific places, as well as universal principles; diverse knowledge systems, in particular local knowledges; institutional inclusion and genuine participation of marginalised peoples, especially initiatives designed by those who have been marginalised; interconnections between water and ecological and social systems, especially supporting further work on the role of water in social and cultural systems; and an end to the imagination of water as a commodity and rivers as conduits for that commodity.

Acknowledgements. This paper emerged from my $\mathrm{PhD}$ research undertaken at the Australian National University; I thank my colleagues there. Many thanks to the people who participated in and supported my field research, in particular those whose words appear in this paper; to John Jansen and Michael Tyghe for field assistance; to Kate Swanson for helpful comments on an earlier version; to Mike Shand for assistance with maps; and to three anonymous reviewers whose feedback contributed to a greatly improved paper. I acknowledge the National Library of Australia for permission to include the image 'Man standing next to an Artesian bore at Bedourie, far south-west Queensland: taken on a survey trip undertaken in 1927 by Rev. J A Barber and Dr George Simpson for the Flying Doctor Scheme', Australian Inland Mission collection, nla.pic-an24669531. 


\section{References}

Ah Chee D, 2002, "Kwatye: indigenous people's connection with kwatye (water) in the Great Artesian Basin" Environment South Australia 9(1) 20 -21

Allan R, 1990, "Climate", in Natural History of the North East Deserts Eds M Tyler, C Twidale, M Davies, C Wells (Royal Society of South Australia Inc., Adelaide) pp 81 - 84

Allon F, Sofoulis Z, 2006, "Everyday water: cultures in transition” Australian Geographer 37(1) $45-55$

Arthur J, 2003 The Default Country: A Lexical Cartography of Twentieth-century Australia (UNSW Press, Sydney)

Australian Government, 2000, "Lake Eyre Basin Intergovernmental Agreement”, Agreement between The Commonwealth of Australia and The State of Queensland and The State of South Australia, http://www.deh.gov.au/water/basins/lake-eyre/agreement.html

Bakker K, 2003 An Uncooperative Commodity: Privatizing Water in England and Wales (Oxford University Press, Oxford)

Bakker K, 2007, “The 'commons' versus the 'commodity': alter-globalization, anti-privatization and the human right to water in the global south" Antipode $39430-455$

Bayly I, 1999, "Review of how indigenous people managed for water in desert regions of Australia" Journal of the Royal Society of Western Australia 82(1) $17-25$

Beale E, 1979 Sturt, the Chipped Idol: A Study of Charles Sturt, Explorer (Sydney University Press, Sydney)

Braun B, 2002 The Intemperate Rainforest: Nature, Culture, and Power on Canada's West Coast (University of Minnesota Press, Minneapolis, MN)

Bulkeley H, Mol A, 2003, "Participation and environmental governance: consensus, ambivalence and debate" Environmental Values $12143-154$

Castree N, Braun B, 2001 Social Nature: Theory, Practice, and Politics (Blackwell, Malden, MA)

Chakrabarty D, 2000 Provincializing Europe: Postcolonial Thought and Historical Difference (Princeton University Press, Princeton, NJ)

Connell D, Dovers S, Grafton Q, 2005, "A critical analysis of the National Water Initiative" The Australasian Journal of Natural Resources Law and Policy 10(1) 81 - 107

Cosgrove D, Petts G, 1990 Water, Engineering and Landscape: Water Control and Landscape Transformation in the Modern Period (Belhaven, London)

Costelloe J, Puckridge J, Reid J, Pritchard J, Hudson P, Bailey V, Good M, 2003, "Environmental flow requirements in arid zone rivers: a case study from the Lake Eyre Basin, central Australia" Water Science and Technology 48(7) $65-72$

Cox R, Barron A, 1998 Great Artesian Basin Resource Study Great Artesian Basin Consultative Council, Fortitude Valley, Queensland

Davidson B, 1969 Australia, Wet or Dry?: The Physical and Economic Limits to the Expansion of Irrigation (Melbourne University Press, Carlton)

Desert Knowledge CRC, 2006, Desert Knowledge CRC, http://www.desertknowledgecrc.com.au

Dunlap T, 1997, "Ecology and environmentalism in the Anglo settler colonies", in Ecology and Empire: Environmental History of Settler Societies Eds T Griffiths, L Robin (Melbourne University Press, South Carlton) pp 76-86

Farmhand Foundation, 2002, Farmhand Foundation, http://www.farmhand.org.au

Gandy M, 2003 Concrete and Clay: Reworking Nature in New York City (MIT Press, Cambridge, MA)

Gandy M, 2008, "Landscapes of disaster: water, modernity, and urban fragmentation in Mumbai" Environment and Planning A $\mathbf{4 0} 108-130$

Gedicks A, 1993, "Resource colonialism and international native resistance", in The New Resource Wars Ed. A Gedicks (South End Press, Boston, MA) pp 13-38

Gibbs L, 2006, "Valuing water: variability and the Lake Eyre Basin, central Australia" Australian Geographer 37(1) $73-85$

Giles E, 1979 Journal of a Forgotten Expedition in 1875 (Sullivan's Cove, Adelaide); first published in 1880 (W K Thomas, Adelaide)

Ginn F, 2008, "Extension, subversion, containment: eco-nationalism and (post)colonial nature in Aotearoa New Zealand" Transactions of the Institute of British Geographers, New Series $33335-353$

Goodall H, 2002, “'The river runs backwards”, in Words for Country: Landscape and Language in Australia Eds T Bonyhady, T Griffiths (UNSW Press, Sydney) pp 30-51

Gregory D, 2001, “(Post)Colonialism and the production of nature”, in Social Nature: Theory, Practice, and Politics Eds N Castree, B Braun (Blackwell, Malden, MA) pp 84-111 
Griffiths T, Robin L, 1997 Ecology and Empire: Environmental History of Settler Societies (Melbourne University Press, South Carlton)

Handmer J, Dorcey A, Smith D, 1991 Negotiating Water: Conflict Resolution in Australian Water Management Centre for Resource and Environmental Studies, Australian National University, Canberra

Head L, 2000 Second Nature: The History and Implications of Australia as an Aboriginal Landscape (Syracuse University Press, New York)

Head L, Muir P, 2006, "Suburban life and the boundaries of nature: resilience and rupture in Australian backyard gardens" Transactions of the Institute of British Geographers, New Series $31505-524$

Head L, Muir P, 2007, "Changing cultures of water in eastern Australian backyard gardens" Social and Cultural Geography $8889-905$

Hercus L, 1985, "Leaving the Simpson Desert" Aboriginal History 9(1/2) 22-43

Hercus L, Clarke P, 1986, "Nine Simpson Desert wells" Archaeology in Oceania 21(1) 51 - 62

Hillman M, 2006, "Situated justice in environmental decision-making: lessons from river management in southeastern Australia" Geoforum 37 695-707

Hillman M, Brierley G, 2005, "A critical review of catchment-scale stream rehabilitation programmes" Progress in Physical Geography 29(1) 50-70

Himley M, 2008, "Geographies of environmental governance: the nexus of nature and neoliberalism" Geography Compass $2433-451$

Howitt R, 2001 Rethinking Resource Management: Justice, Sustainability and Indigenous Peoples (Routledge, London)

Howitt R, Suchet-Pearson S, 2006, "Rethinking the building blocks: ontological pluralism and the idea of 'management'" Geografiska Annaler, Series B: Human Geography 88 323-335

Huggan G, Tiffin H, 2007, "Green postcolonialism" Interventions: International Journal of Postcolonial Studies 9(1) 1 - 11

Idriess I, 1941 The Great Boomerang (Angus and Robertson, Sydney)

Jackson S, 2006, "Compartmentalising culture: the articulation and consideration of Indigenous values in water resource management" Australian Geographer 37 19-31

Jackson S, Storrs M, Morrison J, 2005, "Recognition of Aboriginal rights, interests and values in river research and management: perspectives from northern Australia" Ecological Management and Restoration 6(2) $105-110$

Jazeel T, 2005, “'Nature', nationhood and the poetics of meaning in Ruhuna (Yala) National Park, Sri Lanka" Cultural Geographies 12199 - 227

Jenkin T, 2001, "Place, image and environmental conflict: World Heritage and the Lake Eyre Basin" South Australian Geographical Papers, Royal Geographical Society of South Australia number 6

Johnson J, Murton B, 2007, "Re/Placing native science: Indigenous voices in contemporary constructions of nature" Geographical Research 45(2) $121-129$

Kaika M, 2005 City of Flows: Modernity, Nature, and the City (Routledge, New York)

Kaika M, 2006, "Dams as symbols of modernization: the urbanization of nature between geographical imagination and materiality" Annals of the Association of American Geographers $96276-301$

Kingsford R, 2000, "Protecting rivers in arid regions or pumping them dry?" Hydrobiologia 427 $1-11$

Kingsford R, Davis S, 2002, "WISE on the Cooper", in Proceedings of the Lake Eyre Basin Ministerial Forum, Biennial Conference 25-26 October 2002, Birdsville, pp 29-30

Knighton A, Nanson G, 1994, "Flow transmission along an arid zone anastomosing river, Cooper Creek, Australia” Hydrological Processes 8137 - 154

Langley M, 1969 Sturt of the Murray: father of Australian exploration (Robert Hale, London)

Langton M, 2002, "Freshwater", in Background Briefing Papers (Lingiari Foundation, Broome) pp $43-64$

LEBAF, 2006, "Report from the Second Lake Eyre Basin Aboriginal Forum" 23 - 24 August, Lake Eyre Basin Aboriginal Forum, http://www.lebmf.gov.au/publications/pubs/second-leb-forum.pdf

McHugh S, 1989 The Snowy: The People Behind the Power (William Heinemann, Port Melbourne)

Madigan C, 1946 Crossing the Dead Heart (Australian Society Publication, Melbourne)

Mead E, 1903 Irrigation Institutions (Citizen's Library, New York)

Mead E, 1914, "Irrigation in Victoria", in Handbook to Victoria Eds A Laughton, T Hall (Government Printer, Melbourne) pp $255-268$

Meinig D, 1962 On the Margins of the Good Earth: The South Australian Wheat Frontier 1869-1884 (Rand McNally, Chicago, IL) 
Morgan M, Strelein L, Weir J, 2006, "Authority, knowledge and values: Indigenous Nations engagement in the management of natural resources in the Murray-Darling Basin", in Settling with Indigenous People: Modern Treaty and Agreement-making Eds M Langton, O Mazel, L Palmer, K Shain, M Tehan (Federation Press, Annandale) pp 134-157

Osborne M, Dunn C, 2004, "Talking water: an Australian guidebook for the 21st century", report commissioned by Farmhand Foundation, http://www.farmhand.org.au

Powell J, 1976 Environmental Management in Australia, 1788 - 1914: Guardians, Improvers and Profit (Oxford University Press, Melbourne)

Powell J, 1989 Watering the Garden State: Water, Land and Community in Victoria 1834-1988 (Allen and Unwin, Sydney)

Powell J, 2000, "Snakes and cannons: water management and the geographical imagination in Australia", in Environmental History and Policy: Still Settling Australia Ed S Dovers (Oxford University Press, Melbourne) pp 47-71

Randall A, 1981, "Property entitlements and pricing policies for a maturing water economy" The Australian Journal of Agricultural Economics 25(3) 195 - 219

Ratcliffe F, 1938 Flying Fox and Drifting Sand: The Adventures of a Biologist in Australia (Chatto and Windus, London)

Reid J, 1994, “The Prime Minister's pre-election promise of World Heritage listing for the Lake Eyre Basin: flight or flight of fancy?" The Rangeland Journal 16(2) 273-297

Reisner M, 1986 Cadillac Desert: The American West and its Disappearing Water (Penguin Books, New York)

Robertson M, 2000, "No net loss: wetland restoration and the incomplete capitalization of nature" Antipode $32463-493$

Robin L, 1997, "Ecology: the science of empire?", in Ecology and Empire: Environmental History of Settler Societies Eds T Griffiths, L Robin (Melbourne University Press, South Carlton) pp $63-75$

Robin L, 2007 How a Continent Created a Nation (UNSW Press, Sydney)

Robinson J, 2003, "Postcolonialising geography: tactics and pitfalls" Singapore Journal of Tropical Geography 24(3) $273-289$

Rose D, 1999, "Indigenous ecologies and an ethic of connection", in Global Ethics and Environment Ed. N Low (Routledge, London) pp $175-187$

Rose D, 2003, "Decolonising the discourse of environmental knowledge in settler societies", in Culture and Waste: The Creation and Destruction of Value Eds G Hawkins, S Muecke (Rowman and Littlefield, Lanham, MD) pp 53-72

Rose D, 2004a Reports from a Wild Country: Ethics for Decolonisation (UNSW Press, Sydney)

Rose D, 2004b, "Fresh water rights and biophilia: Indigenous Australian perspectives" Dialogue 23(3) $35-43$

Seddon G, 1994 Searching for the Snowy: An Environmental History (Allen and Unwin, Sydney)

Sheldrick J, 2005, "Goyder's Line: the unreliable history of the line of reliable rainfall", in A Change in the Weather: Climate and Culture in Australia Eds T Sherratt, T Griffiths, L Robin (National Museum of Australia Press, Canberra) pp 56-65

Stokes E, 1986 To the Inland Sea: Charles Sturt's Expedition 1844-45 (Hutchinson Australia, Melbourne)

Suchet S, 2002, “'Totally wild'? Colonising discourses, indigenous knowledges and managing wildlife" Australian Geographer 33(2) 141 - 157

Swyngedouw E, 1999, "Modernity and hybridity: nature, regeneracionismo, and the production of the Spanish waterscape, 1890 - 1930" Annals of the Association of American Geographers $89443-465$

Taylor M, Stokes R, 2005, "When is a river not a river? Consideration of the legal definition of a river for geomorphologists practicing in New South Wales, Australia" Australian Geographer $36183-200$

Timbury F, 1944 The Battle for the Inland: The Case for the Bradfield and Idriess Plans (Angus and Robertson, Sydney)

Toussaint S, Sullivan P, Yu S, 2005, "Water ways in Aboriginal Australia: an interconnected analysis" Anthropological Forum 15(1) 61 - 74

Walker K, Puckridge J, Blanch S, 1997, “Irrigation development on Cooper Creek, central Australia: prospects for a regulated economy in a boom-and-bust ecology" Aquatic Conservation: Marine and Freshwater Ecosystems $763-73$ 
Weir J, 2007, "The traditional owner experience along the Murray River", in Fresh Water: New Perspectives on Water in Australia Eds E Potter, A Mackinnon, S McKenzie, J McKay (Melbourne University Press, Carlton) pp 44-58

Whatmore S, 2002 Hybrid Geographies: Natures Cultures Spaces (Sage, London)

Willems-Braun B, 1997, "Buried epistemologies: the politics of nature in (post)colonial British Columbia" Annals of the Association of American Geographers 87 - 31

World Commission on Dams, 2001, "Dams and development: a new framework for decisionmaking", in The Report of the World Commission on Dams (Earthscan, London)

Worster D, 1992 Rivers of Empire: Water, Aridity, and the Growth of the American West (Oxford University Press, New York)

Yelland L, 2002 Pads, Tracks and Waters: South Australia's Pastoral Stock Routes Primary Industries and Resources South Australia, Adelaide

Young M, McColl J, 2002, "Robust separation: a search for a generic framework to simplify registration and trading in interests in natural resources", CSIRO Land and Water, Policy and Economic Research Unit 
Conditions of use. This article may be downloaded from the E\&P website for personal research by members of subscribing organisations. This PDF may not be placed on any website (or other online distribution system) without permission of the publisher. 